\title{
Spirituality of medical students: associations with empathy and attitudes in the doctor-patient relationship
}

\section{Espiritualidade dos estudantes de Medicina: associações com empatia e atitude na relação médico-paciente

\author{
Julianni Bernardelli Lacombe' ${ }^{10} \mid$ juliannib@yahoo.com.br \\ Emiliana S. Valadares' (D) valadaresemiliana@gmail.com \\ Renata Rodrigues Catani' (D) renata_rcatani@hotmail.com \\ Tânia M. S. Mendonça' (1) taniacore@hotmail.com \\ Helena Borges Martins da Silva Paro' ${ }^{1}$ (D) helenabmsparo@gmail.com \\ Nívea Macedo O. Morales (1) nivea.neuroped@gmail.com
}

\begin{abstract}
Introduction: Currently, the study of the factors that improve interpersonal relationships in patient care and medical education has been considered relevant and necessary. Understanding what precedes empathy and medical interns' and young doctors' attitudes is a relevant topic for health professionals' education and for their academic and professional performance. Although patients and medical students have indicated that spirituality is an important issue, it is not frequently addressed in medical schools.

Objective: This study aims to verify the association between (i) well-being related to spirituality, religiosity and the medical interns' and residents' personal beliefs and (ii) empathy and attitudes in the doctor-patient relationship.

Methods: This was a quantitative, cross-sectional, observational study. A total of 64 undergraduate students in the last years of medical school and 50 residents answered the following self-administered instruments: WHOQOL-SRPB, Jefferson Scale of Empathy, and Patient-Practitioner Orientation Scale. Descriptive statistics, Pearson's correlation and stepwise linear regressions were used to analyze data.

Results: Significant correlations $(p<0.05)$ varying from weak $(r=0.10)$ to moderate $(r=0.39)$ were found. The WHOQOL-SRPB final score affected the global score of empathy $(\mathrm{R} 2=0.12 ; \mathrm{p}<0.00 ; \mathrm{VIF}=1.00)$. The component meaning and purpose in life affected the global score of the patientcentered attitude $(\mathrm{R} 2=0.14 ; \mathrm{p}<0.00 ; \mathrm{VIF}=1.00)$.

Conclusions: Spirituality, religiosity and personal beliefs are associated with patient-centered attitudes and medical interns' and residents' empathy. In general, well-being related to spirituality preceded empathy, and the component meaning and purpose in life preceded patientcentered attitudes. These results imply the need to consider well-being related to spirituality in interns' and residents' education for a better doctor-patient relationship.
\end{abstract}

Keywords: Spirituality; Empathy; Medical Education; Medical Students; Doctor-Patient Relationship.

\section{RESUMO}

Introdução: Na atualidade, considera-se relevante e oportuno estudar os fatores que contribuem para a melhoria das relações interpessoais no contexto da assistência ao paciente e da educação médica. Compreender os preditores em relação à empatia e à atitude do interno de Medicina e do jovem médico é tema em destaque na formação dos profissionais de saúde, no desempenho acadêmico e profissional. A espiritualidade tem sido apontada como tema importante tanto pelos pacientes como pelos estudantes de Medicina, porém ainda pouco abordada nas escolas médicas.

Objetivo: $O$ estudo propõe verificar a associação entre o bem-estar relacionado à espiritualidade, à religiosidade e às crenças pessoais do interno e residente de Medicina e a empatia e a atitude na relação médico-paciente.

Métodos: Trata-se de um estudo observacional, transversal, de abordagem quantitativa. O questionário WHOQOL-espiritualidade, religiosidade e crenças pessoais, a Escala Jefferson de Empatia e a Escala de Orientação Médico-Paciente foram autoaplicados por 64 estudantes dos últimos anos do curso e 50 residentes de Medicina. Realizaram-se estatística descritiva, correlação de Pearson e regressão linear stepwise para análise dos dados.

Resultados: Foram encontradas correlações significativas $(p<0,05)$, variando de fracas $(r=0,10)$ a moderadas $(r=0,39)$. O escore final do WHOQOLSRPB apresentou efeito sobre o escore global de empatia $(R 2=0,12 ; p<0,00 ; \beta=0,35 ; \mathrm{VIF}=1,00)$. Sentido da vida apresentou efeito sobre o escore global da atitude centrada no paciente ( $R 2=0,14 ; p<0,00 ; \beta=0,38 ; \mathrm{VIF}=1,00$ ).

Conclusão: A espiritualidade, a religiosidade e as crenças pessoais foram associadas à atitude centrada no paciente e à empatia dos internos e residentes de Medicina. Em geral, o bem-estar relacionado à espiritualidade foi preditor da empatia, e o sentido da vida, preditor da atitude centrada no paciente. Esses resultados implicam a necessidade de se considerar o bem-estar relacionado à espiritualidade na formação dos internos e residentes para uma melhor qualidade da relação médico-paciente.

Palavras-chave: Espiritualidade; Empatia; Educação Médica; Estudantes de Medicina; Relação Médico-paciente.

1 Universidade Federal de Uberlândia, Uberlândia, Minas Gerais, Brazil.

Chief Editor: Daniela Chiesa

| Associate Editor: Kristopherson Lustosa Augusto

Received on 07/07/20; Accepted on 03/01/21. | Evaluated by double blind review process. 


\section{INTRODUCTION}

In the last decades, re-humanizing medicine has received a widespread concern. The influence of the biomedical model, which has been hegemonic for fourteen centuries, promotes a disease-centered approach, instead of a person-centered care $^{1}$. Since the 20th century, the psychosocial dimension has reintegrated medical education and health practices. It focuses on the construction of a biopsychosocial model, as opposed to the biomedical model. The biopsychosocial model perspective points out the need for doctors to improve their relational skills ${ }^{2}$. Thus, empathy in the doctor-patient relationship, patientcentered care and humanistic medical care are essential and central professional characteristics and skills for doctors ${ }^{3}$.

Empathy is a multidimensional construct in the cognitive, emotional and behavioral domains ${ }^{4-7}$. Higher levels of empathy perceived by patients have a positive correlation with their general satisfaction with doctors, interpersonal trust and higher adherence to treatment ${ }^{8}$, including positive clinical results ${ }^{9}$. Also, lower levels of empathy are associated to a higher probability of medical error ${ }^{10}$.

Patient-centered medicine is one of the main methods used to humanize medicine ${ }^{11}$. It has two principles: personcentered care, which recognizes patients' ideas and emotions towards the disease; and shared decision-making and responsibilities between doctors and patients related to the disease ${ }^{12}$. Patient-centered medicine promotes greater patient and doctor satisfaction and reduces (i) adverse effects associated with prescriptions, (ii) complaints about medical care, (iii) volume of complementary exams, (iv) referrals to specialists, and (v) costs to the healthcare system and to the patient ${ }^{11-13}$.

Understanding what precedes empathy regarding the interns' and young doctors' attitudes is a relevant topic in the education of health professionals and in their academic and professional performance. Some factors have already been associated to higher levels of empathy and person-centered care, such as the female gender ${ }^{5,14}$, the first years of medical school ${ }^{15}$ and the students' psychosocial issues in the beginning of the medical course ${ }^{16}$, working on person-centered medical specialties ${ }^{17}$ and primary care $^{18}$. Egalitarianism, global selfesteem and well-being are positively related to empathy and a patient-centered attitude ${ }^{19}$. Two studies with medical students analyzed spirituality and empathy as correlated variables ${ }^{20,21}$. Another study showed a positive association between spirituality, care and empathy ${ }^{22}$. A recent study associated quality of life to spirituality in medical students and showed that the component meaning and purpose in life was related to higher levels of empathy ${ }^{20}$. No studies were found associating spirituality or spirituality-related quality of life to patientcentered attitudes in the doctor-patient relationship.
Thus, many associations can be established regarding doctors' attitudes and behaviors in the doctor-patient relationship. However, the relationship between behavioral and cognitive aspects - such as spirituality, religiosity and personal beliefs - with empathy and attitudes in the doctor-patient relationship needs clarification. Concerning the importance of this issue in medical education, this research assesses how the perception of well-being (quality of life) related to spirituality, religiosity and personal beliefs are associated to medical interns' and residents' empathy and attitudes in the doctorpatient relationship. Our hypothesis is that the perception of well-being (quality of life) related to spirituality, religiosity and personal beliefs precedes empathy and the patient-centered care in the doctor-patient relationship.

\section{METHODS AND MATERIALS}

\section{Participants}

The local research ethics committee of the Federal University of Uberlândia approved this cross-sectional, quantitative study. A total of 150 medical interns attending the fifth and sixth years of medical school and 214 first- to fourthyear residents in the Clinical Hospital of the Federal University of Uberlândia, Brazil, were eligible for the study. Participant selection was carried out by convenience. Participants were 18 years of age or older.

\section{Instruments}

The following instruments were used:

- The Brazilian version of the World Health Organization Quality of Life - Spirituality, Religiosity and Personal Beliefs (WHOQOL-SRPB) field-test instrument, is a translated, validated, and cross-culturally adapted, self-administered too ${ }^{23}$. It consists of 32 questions focused on aspects of quality of life related to spirituality, religiosity and personal beliefs. Individual items are rated on a 5-point Likert scale, providing eight scores/ components: Spiritual Connection, Meaning and Purpose in Life, Experiences of Awe and Wonder, Wholeness and Integration, Spiritual Strength, Inner Peace, Hope and Optimism, and Faith. The scores range from 20 to 100 . This instrument assesses spiritual, religious or personal beliefs as components of quality of life. Higher scores represent a higher level of positive perceptions of quality of life regarding the SRPB domain ${ }^{24}$.

- Patient-Practitioner Orientation Scale (PPOS) ${ }^{25,26}$. It is a self-administered instrument that assesses the 
Figure 1. Participants

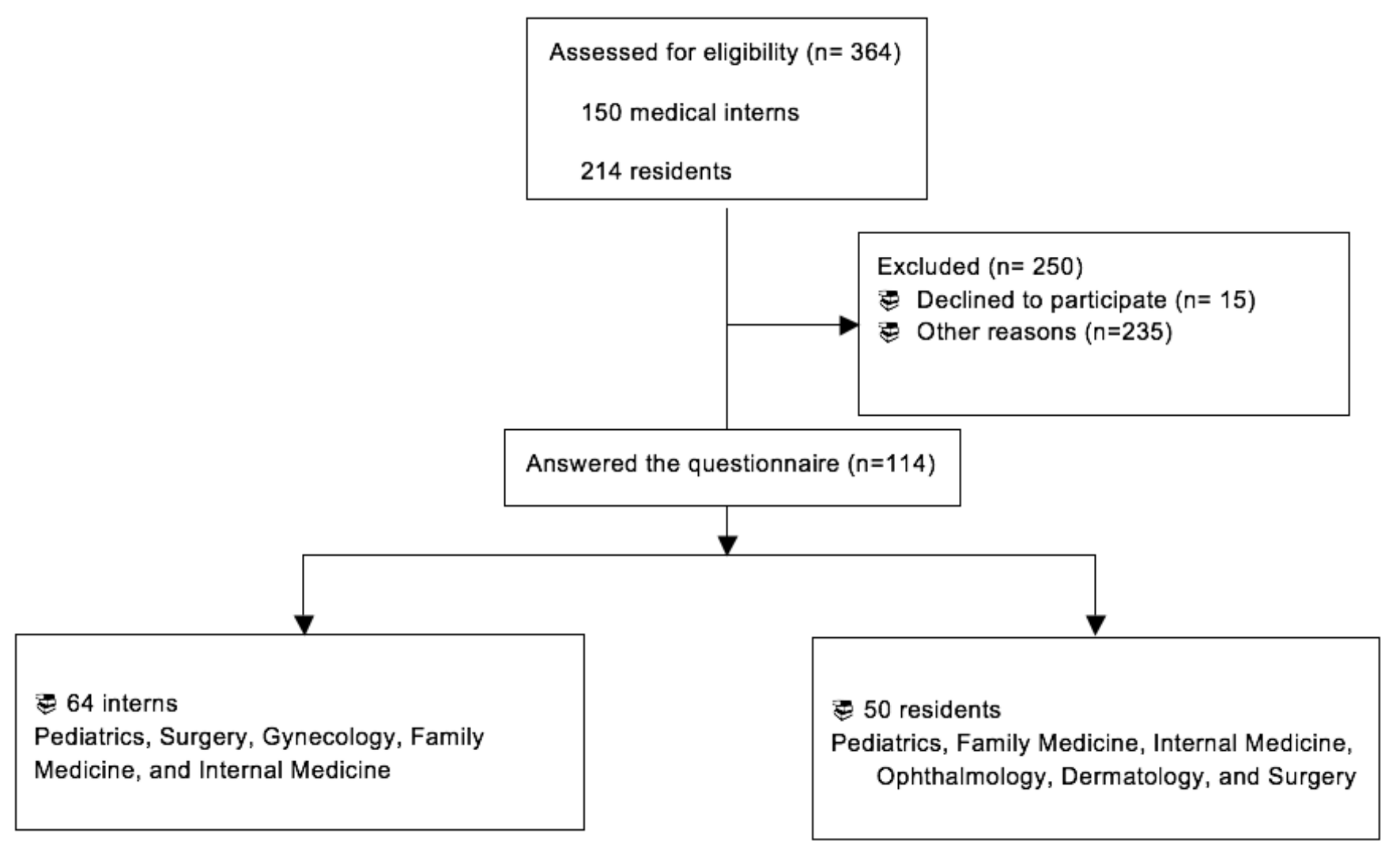

attitudes of patients, doctors and medical students regarding the doctor-patient relationship. It has been validated and translated into Portuguese with appropriate psychometric properties ${ }^{27}$. This scale has 18 items arranged into (i) items related to the dimension of Sharing and (ii) items related to the dimension of Caring. Items are rated in a 6-point Likert scale. Low scores $(\leq 4.57)$ indicate a doctorcentered orientation (high medical control focused on biomedical issues), whereas high scores ( $\geq 5.00$ ) indicate a patient-centered orientation (shared control and focus on the person as a whole). Scores between 4.57 to 5.00 indicate a partially patientcentered orientation.

- $\quad$ The Jefferson Scales of Empathy (JSE) ${ }^{28}$ measures the empathy of medical students and residents. The instrument has 20 items and three domains: Compassionate Care, Perspective-taking, and Walking in Patient's Shoes. The possible answers are rated in a 7-point Likert scale. Empathy is as high as the sum (20 to 140) of the answers to all items, with a maximum score of 140 points. The version for medical students (JSE-S Version), validated to be used in Brazil' ${ }^{29}$, was designed to reflect students' orientation or empathic attitude in medical care.
The Cronbach's alpha coefficients of the validated questionnaires are: WHOQOL-SRPB (0.879), PPOS (0.714), and JSE (0.805).

A sociodemographic questionnaire identified age, gender, marital status, religious affiliation, current year of medical school, current specialty (residents) or intended specialty (interns), and religious involvement (low or high). All questionnaires were self-administered.

\section{Procedures}

Medical interns and residents were approached during outpatient activities in the Clinical Hospital of the Federal University of Uberlândia and in the Primary-Care Health Centers after prior authorization of the responsible professor/ preceptor. They were invited to answer the WHOQOL-SRPB, PPOS and JSE scales and a socio-demographic questionnaire, all self-administered.

The intended and ongoing specialties were stratified into person-centered and technology-centered ones ${ }^{18}$.

At Federal University of Uberlândia, the Medical School program lasts six years, of which the first three are the preclinical years and the last three are the clinical years. The pedagogical model is structured into modules. Knowledge is subdivided into two distinct stages - basic and curricular internship-, and most of the learning scenarios are restricted to the hospital environment. 


\section{Statistical Analysis}

Descriptive statistics characterized the sample and determined the measures of central tendency and position of the data (mean, median, standard deviation, frequency and percentage). The normality of the data was verified by the Shapiro-Wilks test and the variables will be analyzed considering a normal distribution, as suggested in the literature ${ }^{30}$. Pearson's correlation determined the association between the WHOQOLSRPB (and its subdomains) and all the other study variables (JSE-S and its three domains, PPOS and its two domains, and the socio-demographic data (being an intern, a resident, gender, age, religious involvement). Variables with moderate correlations $(r>0.3)^{31}$ with $\mathrm{p}<0.05$ were used in the stepwise linear regressions. Independent variables: WHOQOL-SRPB (and its domains), gender, age, religious involvement, being an intern, and being a resident. Dependent variables: JSE-S, and PPOS and their domains. $\mathrm{R}^{2}$ assessed the goodness-of-fit of the model. Multicollinearity was accepted when the variance inflation factor (VIF) value was $>10$ and / or when the tolerance score was $<0.132$. Internal consistency was assessed through

Table 1. Medical interns' and residents' sociodemographic data.

\begin{tabular}{|c|c|c|}
\hline Variable & $\mathbf{N}$ & $\%$ \\
\hline \multicolumn{3}{|l|}{ Sex } \\
\hline Female & 77 & $67.5 \%$ \\
\hline \multicolumn{3}{|l|}{ Marital status } \\
\hline Single & 103 & $90.4 \%$ \\
\hline \multicolumn{3}{|l|}{ Religion } \\
\hline Did not answer & 3 & $2.6 \%$ \\
\hline Catholic & 51 & $44.7 \%$ \\
\hline Afro-Brazilian & 1 & $0.9 \%$ \\
\hline Protestant & 13 & $11.4 \%$ \\
\hline Spiritism & 21 & $18.4 \%$ \\
\hline None & 23 & $20.2 \%$ \\
\hline Other & 2 & $1.8 \%$ \\
\hline
\end{tabular}

Religious involvement

$\begin{array}{lll}\text { High } & 67 & 58.77 \% \\ \text { Low } & 47 & 41.22 \%\end{array}$

Medical Interns:

Intended Specialty

$\begin{array}{ccc}\text { Person-centered } & 32 & 50 \% \\ \text { Technology-centered } & 15 & 23.43 \% \\ \text { Did not answer } & 17 & 26.56 \%\end{array}$

Medical Residents:

Current Specialty

\begin{tabular}{ccc} 
Person-centered & 45 & $90 \%$ \\
Technology-centered & 5 & $10 \%$ \\
\hline
\end{tabular}

Cronbach's alpha. The software SPSS 20.0 analyzed the data. The alpha level was set at 0.05 .

\section{RESULTS}

Of the 114 participants, $56.2 \%$ are interns attending the fifth and sixth years of medical school and $43.9 \%$ are first to fourth-year residents.

The mean age was 25.9 years \pm 0.6 , with a predominance of female participants (67.5\%). Catholicism (44.7\%) was the most frequent religion among the participants, as well as high religious involvement (43\%) (Table 1).

Table 2 shows the mean scores of the JSE-S, PPOS and WHOQOL-SRPB scales. For each WHOQOL-SRPB domain, the lowest and highest mean were Faith $(69.29 \pm 23.72)$ and Meaning and Purpose in Life $(82.65 \pm 13.56)$, respectively. In the PPOS, the final score $(4.59 \pm 0.43)$ indicates a partially patientcentered orientation. The final score of the JSE (118.56 \pm 10.25$)$ indicates a number close to the maximum value of 140 .

Table 3 shows Pearson's coefficient correlations between WHOQOL-SRPB (and its domains S1 to S8), JSE-S and

Table 2. Mean and standard deviation of the instruments'scores

\begin{tabular}{ccccc}
\hline Variable & Mean & SD & Minimum & Maximum \\
\hline WOQOL-SRPB & & & & \\
S1 & 70.40 & 22.92 & 20 & 100 \\
S2 & 82.65 & 13.53 & 40 & 100 \\
S3 & 73.89 & 12.51 & 45 & 100 \\
S4 & 73.60 & 12.91 & 35 & 100 \\
S5 & 72.57 & 18.98 & 20 & 100 \\
S6 & 72.77 & 11.60 & 40 & 100 \\
S7 & 76.16 & 11.58 & 45 & 100 \\
S8 & 69.29 & 23.72 & 20 & 100 \\
\hline Total Score & 74.02 & 12.17 & 36.25 & 99.37 \\
\hline JSE & & & & \\
Sub1 & 49.27 & 4.62 & 37 & 56 \\
Sub2 & 8.48 & 2.77 & 2 & 14 \\
Sub3 & 60.81 & 7.13 & 39 & 70 \\
\hline Total Score & 118.56 & 10.25 & 89 & 136 \\
\hline PPOS & & & & \\
Share & 4.21 & 0.63 & 2.33 & 5.77 \\
Care & 4.96 & 0.43 & 3.66 & 6.00 \\
\hline Total Score & 4.59 & 0.43 & 3.21 & 5.55 \\
\hline
\end{tabular}

WHOQOL-SRPB:WHOQOL-Spirituality, religiosity, and personal beliefs; JSE: Jefferson Scale of Empathy PPOS: Patient-Practitioner Orientation Scale. S1: Spiritual connection; S2: Meaning and purpose in life; S3 Experiences of awe and wonder; S4: Wholeness and integration; S5: Spiritual strength; S6: Inner peace; S7: Hope and optimism; S8: Faith. Sub1: Compassion; Sub2:Walking in Patient's Shoes; Sub3: Perspectivetaking. SD: Standard deviation. 
its domains, PPOS and its domains, being an intern, being a resident, gender, age, and religious involvement. Significant correlations ( $p$-value $<0.05)$ varying from weak $(r=0.10)$ to moderate $(r=0.30)$ were found. Moderate correlations with $r$ $>0.3$ were found: (a) Perspective-taking: Spiritual Connection ( $r=0.309 ; \mathrm{p}<0,01)$, Wholeness and Integration $(r=0.342 ; \mathrm{p}<$ 0.01 ) and WHOQOL-SRPB global score ( $r=0.394 ; p<0.01)$; (b) Final JSE score: Wholeness and Integration ( $r=0.337 ; p<0.01)$,
Inner Peace $(r=0.325 ; \mathrm{p}<0.01)$, WHOQOL-SRPB global score $(r=0.352 ; p<0.01)$; (c) Sharing : Wholeness and Integration ( $r=0.334 ; p<0.01) ;(d)$ Caring: WHOQOL-SRPB global score $(r$ $=0.312 ; p<0.01) ;(e)$ PPOS Total score: Meaning and Purpose in Life $(r=0.323 ; p<0.01)$, Inner Peace $(r=0.315 ; p<0.01)$ e WHOQOL-SRPB global score $(r=0.358 ; p<0.01)$.

The results and coefficients after multiple regression analysis (stepwise) are depicted in Table 4. In the final

Table 3. Pearson's correlation coefficients between spirituality, empathy, attitudes and sociodemographic characteristics.

\begin{tabular}{|c|c|c|c|c|c|c|c|c|c|c|c|c|c|c|}
\hline Variable & & $\begin{array}{l}\text { Student/ } \\
\text { resident }\end{array}$ & Age & Gender & $\begin{array}{c}\text { Religious } \\
\text { involvement }\end{array}$ & $\begin{array}{c}\text { S1 } \\
\text { Connection }\end{array}$ & $\begin{array}{c}\text { S2 } \\
\text { Meaning } \\
\text { and purpose } \\
\text { in life }\end{array}$ & $\begin{array}{c}\text { S3 } \\
\text { Experiences } \\
\text { of awe and } \\
\text { wonder }\end{array}$ & $\begin{array}{c}\text { S4 } \\
\text { Wholeness } \\
\text { and } \\
\text { Integration }\end{array}$ & $\begin{array}{c}\text { S5 } \\
\text { Spiritual } \\
\text { strength }\end{array}$ & $\begin{array}{c}\text { S6 } \\
\text { Peace- } \\
\text { Harmony }\end{array}$ & $\begin{array}{c}\text { S7 } \\
\text { Hope }\end{array}$ & $\begin{array}{c}\text { S8 } \\
\text { Faith }\end{array}$ & $\begin{array}{l}\text { WHOQOL- } \\
\text { SRPB } \\
\text { Global } \\
\text { score }\end{array}$ \\
\hline \multicolumn{15}{|l|}{ JSE } \\
\hline Final Score & (r) & -.117 & -.093 & $.203^{*}$ & $.222^{*}$ & $.237^{*}$ & $.252^{* *}$ & $.272^{* *}$ & $.337^{* *}$ & $.250 * *$ & $.325^{* *}$ & $.191^{*}$ & $.199^{*}$ & $.352^{* *}$ \\
\hline Sub1 & $(r)$ & -.141 & .102 & $.206^{*}$ & .166 & .072 & .122 & .088 & .175 & .091 & $.226^{*}$ & .113 & .044 & .144 \\
\hline Sub2 & (r) & -.066 & .048 & .023 & -.094 & -.037 & .121 & .071 & .066 & -.021 & .075 & .108 & .066 & .041 \\
\hline Sub3 & (r) & -.051 & .086 & .149 & $.248^{* *}$ & $.309^{* *}$ & $.236^{*}$ & $.306^{* *}$ & $.342^{* *}$ & $.309^{* *}$ & $.291^{* *}$ & .160 & $.283^{* *}$ & $.394^{* *}$ \\
\hline \multicolumn{15}{|l|}{ PPOS } \\
\hline Final Score & (r) & .123 & .071 & .163 & .115 & $.189 *$ & $.323^{* *}$ & $.336^{* *}$ & $.364^{* *}$ & $.233^{*}$ & $.315^{* *}$ & $.266^{* *}$ & .164 & $.358^{* *}$ \\
\hline Share & (r) & .087 & -.029 & .114 & .129 & .122 & $.269^{* *}$ & $.289^{* *}$ & $.334^{* *}$ & .151 & $.275^{* *}$ & $.212^{*}$ & .097 & $.283^{* *}$ \\
\hline Care & (r) & .121 & .185 & .161 & .043 & $.201^{*}$ & $.257^{* *}$ & $.255^{* *}$ & $.246^{* *}$ & $.250^{* *}$ & $.236^{*}$ & $.228^{*}$ & $.190^{*}$ & $.312^{* *}$ \\
\hline
\end{tabular}

${ }^{*} p<0,05 * * p<0.01$.WHOQOL-SRPB:WHOQOL Spirituality, religiosity, and personal beliefs; JSE: Jefferson Scale of Empathy PPOS. Patient-Practitioner Orientation Scale. Sub1: Compassion; Sub2: Walking in Patient's Shoes; Sub3: Perspective-taking.

Table 4. Multiple linear regression analysis of variables moderately correlated with the components and total score of WHOQOL - spirituality/religiosity/personal beliefs and sociodemographic characteristics

\begin{tabular}{|c|c|c|c|c|c|c|c|c|c|c|}
\hline $\begin{array}{l}\text { DEPENDENT } \\
\text { VARIABLES }\end{array}$ & $\begin{array}{c}\text { INDEPENDENT } \\
\text { VARIABLES }\end{array}$ & Constant & $\mathrm{R} 2$ & $\begin{array}{c}\text { Adjusted } \\
\text { R2 }\end{array}$ & $F$ & pvalueF & & & & \\
\hline \multirow[t]{2}{*}{ Perspective-taking } & & 43.62 & .15 & .14 & 19.64 & $.00^{* *}$ & $\beta$ & pvalue $\beta$ & VIF & Tolerance \\
\hline & $\begin{array}{l}\text { WHOQOL-SRPB } \\
\text { Global score }\end{array}$ & & & & & & .39 & $.00^{* *}$ & 1.00 & 1.00 \\
\hline \multirow[t]{3}{*}{ Compassion } & & 39.47 & .09 & .07 & 5.45 & $.01^{* *}$ & $\beta$ & pvalue $\beta$ & VIF & Tolerance \\
\hline & Sex & & & & & & .20 & $.03^{*}$ & 1.00 & 1.00 \\
\hline & S6-Inner peace & & & & & & .22 & $.01^{* *}$ & 1.00 & 1.00 \\
\hline \multirow[t]{2}{*}{ JSE Global score } & & 96.65 & .12 & .11 & 15.16 & $.00 * *$ & $\beta$ & pvalue $\beta$ & VIF & Tolerance \\
\hline & $\begin{array}{l}\text { WHOQOL-SRPB } \\
\text { Global score }\end{array}$ & & & & & & .35 & $.00 * *$ & 1.00 & 1.00 \\
\hline \multirow[t]{2}{*}{ Share } & & 3.05 & .10 & .09 & 12.72 & $.00^{* *}$ & $\beta$ & pvalue $\beta$ & VIF & Tolerance \\
\hline & $\begin{array}{l}\text { S4-Wholeness } \\
\text { and Integration }\end{array}$ & & & & & & .32 & $.00^{* *}$ & 1.00 & 1.00 \\
\hline \multirow[t]{2}{*}{ Care } & & 4.05 & .11 & .10 & 13.06 & $.00^{* *}$ & $\beta$ & pvalue $\beta$ & VIF & Tolerance \\
\hline & $\begin{array}{l}\text { S2-Meaning and } \\
\text { purpose in life }\end{array}$ & & & & & & .33 & $.00^{* *}$ & 1.00 & 1.00 \\
\hline \multirow[t]{2}{*}{ PPOS Global score } & & 3.53 & .14 & .13 & 18.08 & $.00^{* *}$ & $\beta$ & pvalue $\beta$ & VIF & Tolerance \\
\hline & $\begin{array}{l}\text { S2-Meaning and } \\
\text { purpose in life }\end{array}$ & & & & & & .38 & $.00^{* *}$ & 1.00 & 1.00 \\
\hline
\end{tabular}

${ }^{*} p<0,05{ }^{* *} p<0.01$. WHOQOL-SRPB: WHOQOL Spirituality, religiosity and personal beliefs; JSE: Jefferson Scale of Empathy; PPOS: Patient-

Practitioner Orientation Scale 
regression model, the following variables were significantly associated: (a) Perspective-taking: WHOQOL-SRPB global score; (b) Compassion: Inner Peace and Gender; (c) Final JSE Score: WHOQOL-SRPB global score; (d) Sharing: Wholeness and Integration; (e) Caring: Meaning and Purpose in Life; (f) Total PPOS Score: Meaning and Purpose in Life. Multicollinearity was not a problem in the regression model when verifying both VIF and tolerance scores.

\section{DISCUSSION}

This research assessed the perception of well-being related to spirituality, religiosity and personal beliefs and its association with empathy and attitudes of medical interns and residents in relation to the doctor-patient relationship. According to our hypothesis, empathy and patient-centered attitude were in general significantly associated with wellbeing related to spirituality, religiosity, and personal beliefs. The spiritual quality of life predicted the final scores of empathy and perspective-taking. The component meaning and purpose in life predicted the global patient-centered attitude. In addition, inner peace predicted compassion, while wholeness and integration predicted the domain sharing of the patientcentered care.

\section{Spirituality and Empathy}

This study found that levels of empathy were positively associated with the perception of well-being related to spirituality, religiosity, and personal beliefs. WHOQOL-SRPB Final Score predicted the global empathy and perspectivetaking. Inner peace predicted the domain compassion of JSE. Other studies have found a positive association between spirituality, care, and empathy ${ }^{22,42}$.

Previous studies have described that burnout is inversely correlated to empathy, while personal well-being and quality of life showed a positive correlation with empathy scores in medical students ${ }^{7,43}$. A recent study with a sample of students has indicated that empathy in the doctor-patient relationship is associated with well-being related to spirituality - Meaning and Purpose in Life ${ }^{20}$. Therefore, some factors such as wellbeing $^{7}$, depression ${ }^{43}$, and burnout ${ }^{44}$ are correlated to empathy, supporting the idea that empathy is not only an isolated cognitive dimension.

The perspective-taking of empathy - the cognitive dimension - shows a larger number of associations with the perception of well-being related to spirituality and its components. It means that the cognitive dimension of empathy - the ability to consider the perspective of others ${ }^{10}$ - is related to factors connected with satisfaction with spirituality/religiosity/ inner beliefs of medical interns and young doctors. The search for questions about existence and the meaning and purpose in life could give a transcendental meaning to life and work as a strategy to deal with human suffering, reflecting on higher empathic behavior.

Inner peace, a component of the WHOQOL-SRPB, was correlated to compassion. In fact, this study reinforces that the expression of compassion in the interpersonal relationship stimulates us to understand we are part of a whole, which could be related to the feeling of inner peace ${ }^{45}$. The inner peace aspect, which integrates the component of spirituality, is defined as: "The source of this peace comes from within the person and may be linked to the relationship that this person has with God or may originate from this person's belief in a moral code or a set of beliefs"24. Also, gender was a predictive factor in the compassion domain of empathy. Our study replicates the tendency described in the literature on the existence of higher empathy levels in female medical students ${ }^{5,14}$. Previous studies have suggested that women are more receptive to emotional cues than men. This quality may contribute to a better understanding of others and a better empathic relationship with the patient ${ }^{25}$, as well as to the female socialization skills ${ }^{26}$.

Empathy and religious involvement showed a weak correlation. The multivariate regression analysis indicated that the perception of well-being related to spirituality, religiosity and personal beliefs predicted empathy. This result better explained the model in relation to religious involvement. Previous studies have pointed out that religiosity has an association with better mental health results ${ }^{29,46}$, but other studies have shown no association between religious beliefs and empathy ${ }^{31,22}$. Religiosity is defined as how much an individual believes in, follows and practices a religion. It may be organizational (to attend a church or a religious temple or non-organizational (to pray, read books, watch religious TV shows) ${ }^{32}$. Having a religious affiliation or religious involvement was not equally associated with empathy as some domains of spirituality were.

In this sense, when we consider medical education and the empathy approach, we need to broaden the focus and search for other factors that influence students' and young doctors' empathic behavior towards patients. The following ideas may provide essential conditions for professional education $^{33}$ and affect their practice - empathic behavior activities during medical training that stimulate the study of spirituality by acknowledging people's subjectivity, resources to understand self-care and self-knowledge, and debates about transcendence, inner peace, mechanisms of resilience, and topics on physicians' well-being. Moreover, such activities may be a mechanism used to face stress, to keep oneself highly resilient and to improve the quality of life ${ }^{34}$ of interns 
and residents. Medical schools all over the world have come together to include spirituality in their medical curriculum ${ }^{35-37}$.

\section{Spirituality and Patient-centered Medicine}

Our study indicated a positive association between the perception of well-being related to spirituality/religiosity/ beliefs and a more patient-centered medical attitude in a sample of medical interns and residents who have been training their skills in clinical practice. Meaning and purpose in life predicted the patient-centered care - PPOS global score - and the Caring domain. Wholeness and integration were a predictor factor of the PPOS Sharing domain.

If empathy is a critical factor for promoting patientcentered care $^{38}$, and some studies have shown that it is also related to spirituality ${ }^{39,20}$, the perception of well-being related to spirituality has an association with patient-centered care, as identified in our study. Research studies have described that doctors' spirituality and religiosity influence clinical decisions, as well as the doctor-patient relationship ${ }^{40}$.

This study demonstrates that the component wholeness and integration is associated with sharing. Sharing concerns whether power and control should be shared between the doctor and the patient and to what degree doctors should share information with their patients ${ }^{41}$. Wholeness and integration regards, for example, "to what extent do you feel any connection between your mind, body and soul? How satisfied are you with having a balance between mind, body and soul? To what extent do you feel the way you live is in accordance with what you feel and think? How much do your beliefs help you create coherence (harmony) between what you do, think and feel?." Thus, the balance among these three dimensions (body, mind and soul) and the help of beliefs as a mechanism to seek harmony can provide a patient-centered care on sharing decisions and responsibilities between doctors and patients with common goals regarding the disease.

This study highlights the association of meaning and purpose in life with a patient-centered care, as well as the Caring domain. Caring reflects whether participants consider patients' expectations, feelings and emotions as critical elements ${ }^{41}$. This study demonstrates that participants report that the component meaning and purpose in life as one of the most important of the WHOQOL-SRPB instrument. Meaning and purpose in life concerns, for example, "to what extent do you find a meaning in life? To what extent does caring for others provide meaning in life for you? To what extent do you feel that your life has a purpose? How much do you feel you are here for a reason?". In essence, caring for others - caring for the patient - will enable a meaning or purpose in life, and, at the same time, having meaning and purpose in life can provide a more patient-centered care. This is still an unexplored topic in medical schools.

Thus, this study indicates that having a more patientcentered care may not only require training throughout the program stages, but also knowledge and more experience in some domains of spirituality, especially those related to purpose and meaning in life. Therefore, (i) an approach in the context of medical education focused on the medical student's spirituality, (ii) activities that stimulate finding a meaning and purpose in life and possible devices to help develop them, and (iii) understanding how to deal with emotions and expectations can produce perceptions of positive well-being related to spirituality. They can also result in patient-centered care in the doctor-patient relationship.

\section{Study Limitations}

We used self-administered questionnaires on empathy and doctor-patient orientation, which can be influenced by the bias of social desirability, biasing the responses of interns and residents to what is socially accepted. However, this limitation and subjectivity of responses is inherent to this type of study.

Another limitation concerns the sample restriction to the interns attending the last two years of medical school and residents in the first four years of residency, so the data does not represent the other students. New studies have included students attending the first years, as there are indications that this period in higher education is a significant predictor of higher levels of empathy ${ }^{20}$.

There is also the risk of selection bias - $31.3 \%$ of eligible individuals participated in the study. The number is appropriate, but there may be a "Healthy entrant effect" which, in this case, may mean that more empathetic, more religious and spiritualized students are more likely to answer the questionnaire than less empathic and religious ones. In this sense, $67.5 \%$ of the study participants were women; $90 \%$ of medical residents and $50 \%$ of medical interns had chosen or intended to choose a "person-centered" specialty. Therefore, the selection bias can be justified by the fact that the majority of the sample consists of women and students and doctors with a choice of "person-centered" specialties, factors that are related to higher levels of empathy, according to previous studies ${ }^{5,14,16}$.

Although the response rate was satisfactory for the eligible individuals (31.3\%) in this study, the research was carried out in a single higher education institution and thus, external validity was not verified. However, the total WHOQOLSRPB score (74.02) in our study group is similar to the results of other studies20 (ranging from 71.76 to 73.5 ) in a similar population - medical students in Brazil - which reinforces the appropriateness of the selection method and the sample size. 


\section{CONCLUSION}

Well-being related to the spirituality of the medical interns and residents has a positive association with patientcentered care and empathic behavior. This study enhances our understanding on the need to consider spirituality and beliefs in medical education. Debates on these issues, especially on the meaning and purpose in life and inner peace as part of the medical curriculum, might lead to better results in the humanization of medical practice.

\section{AUTHORS' CONTRIBUTIONS}

Julianni Bernardelli Lacombe contributed to the study design, data collection, analysis, and interpretation of data. Julianni Bernardelli Lacombe produced the original document and provided the final review of this paper. Emiliana S. Valadares and Renata Rodrigues Catani contributed to data collection, analysis, and interpretation of data. Tânia M. S. Mendonça contributed to the statistical analysis and interpretation of data. Helena Borges Martins da Silva Paro contributed to the study design, data collection, literature search, and document review. Nívea Macedo O. Morales contributed to the study design, literature acquisition, interpretation of results, document review, and final approval of the version for publication. All authors approved the final version of the manuscript for submission.

\section{CONFLICTS OF INTEREST}

The authors declare no conflicts of interest.

\section{SOURCES OF FUNDING}

The authors declare no external sources of funding for this research.

\section{REFERENCES}

1. King LS. Editorial: The humanization of medicine. JAMA. 1975;231(7):738-9.

2. Roter $D$. The enduring and evolving nature of the patient-physician relationship. Patient Educ Couns. 2000;39(1):5-15.

3. Institute of Medicine (US) Committee on Quality of Health Care in America. Crossing the Quality Chasm: A New Health System for the 21st Century [Internet]. Washington (DC): National Academies Press (US); 2001 [access in 23 may 2017]. Available from: http://www.ncbi.nlm.nih.gov/books/ NBK222274/.

4. Hojat M. Empathy in Patient Care: Antecedents, Development, Measurement, and Outcomes. Springer Science \& Business Media; 2007. p. 303.

5. Kataoka HU, Koide N, Ochi K, Hojat M, Gonnella JS. Measurement of empathy among Japanese medical students: psychometrics and score differences by gender and level of medical education. Acad Med J Assoc Am Med Coll. 2009;84(9):1192-7.

6. West CP, Huschka MM, Novotny PJ, Sloan JA, Kolars JC, Habermann TM, et al. Association of Perceived Medical Errors With Resident Distress and Empathy: A Prospective Longitudinal Study. JAMA. 2006;296(9):1071.
7. Thomas MR, Dyrbye LN, Huntington JL, Lawson KL, Novotny PJ, Sloan JA, et al. How Do Distress and Well-being Relate to Medical Student Empathy? A Multicenter Study. J Gen Intern Med. 2007;22(2):177-83.

8. Hojat M, Louis DZ, Maxwell K, Markham F, Wender R, Gonnella JS Patient perceptions of physician empathy, satisfaction with physician, interpersonal trust, and compliance. Int J Med Educ. 2010;1:83-7.

9. Hojat M, Louis DZ, Markham FW, Wender R, Rabinowitz C, Gonnella JS Physicians' Empathy and Clinical Outcomes for Diabetic Patients: Acad Med. 2011;86(3):359-64.

10. West CP, Huschka MM, Novotny PJ, Sloan JA, Kolars JC, Habermann TM, et al. Association of perceived medical errors with resident distress and empathy: a prospective longitudinal study. JAMA. 2006;296(9):1071-8.

11. Ribeiro MMF, Amaral CFS. Medicina centrada no paciente e ensino médico: a importância do cuidado com a pessoa e o poder médico. Rev Bras Educ Med. 2008;32(1):90-7.

12. Stewart M, Brown JB, Donner A, McWhinney IR, Oates J, Weston WW et al. The impact of patient-centered care on outcomes. J Fam Pract 2000;49(9):796-804

13. Little $P$, Everitt $H$, Williamson I, Warner G, Moore M, Gould C, et al. Preferences of patients for patient centred approach to consultation in primary care: observational study. BMJ. 2001;322(7284):468-72.

14. Hojat M. Empathy in Patient Care: Antecedents, Development, Measurement, and Outcomes. Springer Science \& Business Media; 2007. p. 303.

15. Chen DCR, Kirshenbaum DS, Yan J, Kirshenbaum E, Aseltine RH Characterizing changes in student empathy throughout medical school. Med Teach. 2012;34(4):305-11.

16. Krupat E, Hiam CM, Fleming MZ, Freeman P. Patient-centeredness and its correlates among first year medical students. Int J Psychiatry Med. 1999;29(3):347-56.

17. Harsch HH. The Role of Empathy in Medical Students' Choice of Specialty Acad Psychiatry. 15 de janeiro de 2014;13(2):96-8.

18. Chen $D$, Lew R, Hershman W, Orlander J. A cross-sectional measurement of medical student empathy. J Gen Intern Med. 2007;22(10):1434-8.

19. van Ryn M, Hardeman RR, Phelan SM, Burke SE, Przedworski J, Allen ML, et al. Psychosocial predictors of attitudes toward physician empathy in clinical encounters among 4732 1st year medical students: a report from the CHANGES study. Patient Educ Couns. 2014;96(3):367-75.

20. Damiano RF, Ribeiro LMA, dos Santos AG, da Silva BA, Lucchetti G. Empathy is Associated with Meaning of Life and Mental Health Treatment but not Religiosity Among Brazilian Medical Students. J Relig Health.;56(3):1003-17.

21. Hull SK, DiLalla LF, Dorsey JK. Student attitudes toward wellness, empathy, and spirituality in the curriculum. Acad Med J Assoc Am Med Coll. 2001;76(5):520.

22. Markstrom CA, Huey E, Stiles BM, Krause AL. Frameworks of Caring and Helping in Adolescence: Are Empathy, Religiosity, and Spirituality Related Constructs? Youth Soc. 2010;42(1):59-80.

23. Panzini RG, Maganha C, da Rocha NS, Bandeira DR, Fleck MP. Brazilian validation of the Quality of Life Instrument/spirituality, religion and personal beliefs. Rev Saude Publica. 2011;45(1):153-65.

24. Fleck MP, Skevington S. Explaining the meaning of the WHOQOL-SRPB. Arch Clin Psychiatry São Paulo. 2007;34:146-9.

25. Hojat M, Gonnella JS, Mangione S, Nasca TJ, Veloski JJ, Erdmann JB, et al. Empathy in medical students as related to academic performance, clinical competence and gender. Med Educ. 2002;36(6):522-7.

26. Hojat M, Gonnella JS, Nasca TJ, Mangione S, Vergare M, Magee M. Physician empathy: definition, components, measurement, and relationship to gender and specialty. Am J Psychiatry. 2002;159(9):1563-9 [access in 6 sep 2020]. Available from: http://www.journals.cambridge.org/abstract S147895150303027X

27. Pereira CMAS, Amaral CFS, Ribeiro MMF, Paro HBMS, Pinto RMC, Reis LET, et al. Cross-cultural validation of the Patient-Practitioner Orientation Scale (PPOS). Patient Educ Couns. 2013;91(1):37-43. 
28. Paro HBMS, Daud-Gallotti RM, Tibério IC, Pinto RMC, Martins MA. Brazilian version of the Jefferson Scale of Empathy: psychometric properties and factor analysis. BMC Med Educ. 2012;12:73.

29. AbdAleati NS, Zaharim NM, Mydin YO. Religiosity and Mental Health: Systematic Review Study. J Relig Health. 2016;55(6):1929-37.

30. Torman VBL, Coster R, Riboldi J. Normality of variables: diagnosis methods and comparison of some nonparametric tests by simulation. Rev HCPA. 2012;32:227-34.

31. Santos MA, Grosseman S, Morelli TC, Giuliano ICB, Erdmann TR. Empathy differences by gender and specialty preference in medical students: a study in Brazil. Int J Med Educ. 2016;7:149-53.

32. Koenig $\mathrm{H}, \mathrm{McC}$ Culloug $M$, Larson $D$. Handbook of religion and health: $A$ century of research reviewed historical context. 2001;

33. Reginato V, Benedetto MACD, Gallian DMC. Espiritualidade e saúde: uma experiência na graduação em medicina e enfermagem. Trab Educ E Saúde. 2016;14(1):237-55.

34. Krägeloh CU, Henning MA, Billington R, Hawken SJ. The relationship between quality of life and spirituality, religiosity, and personal beliefs of medical students. Acad Psychiatry J Am Assoc Dir Psychiatr Resid Train Assoc Acad Psychiatry. 2015;39(1):85-9.

35. Fortin AH, Barnett KG. STUDENTJAMA. Medical school curricula in spirituality and medicine. JAMA. 2004;291(23):2883.

36. Lucchetti G, de Oliveira LR, Leite JR, Lucchetti ALG, SBRAME Collaborators. Medical students and controversial ethical issues: results from the multicenter study SBRAME. BMC Med Ethics. 2014;15:85.

37. Lucchetti G, Granero A. Integration of spirituality courses in Brazilian medical schools. Med Educ. 2010;44(5):527.
38. Koenig HG. Religion, Spirituality, and Medicine: Application to Clinical Practice. JAMA. 2000;284(13):1708.

39. DiLalla LF, Hull SK, Dorsey JK, Department of Family and Community Medicine, Southern Illinois University School of Medicine, Carbondale 62901, USA. Idilalla@siu.edu. Effect of gender, age, and relevant course work on attitudes toward empathy, patient spirituality, and physician wellness. Teach Learn Med. 2004;16(2):165-70.

40. Daaleman TP. Religion, spirituality, and the practice of medicine. J Am Board Fam Pract. 2004;17(5):370-6.

41. Krupat E, Rosenkranz SL, Yeager CM, Barnard K, Putnam SM, Inui TS. The practice orientations of physicians and patients: the effect of doctorpatient congruence on satisfaction. Patient Educ Couns. 2000;39(1):49-59.

42. Bradley C. The interconnection between religious fundamentalism, spirituality, and the four dimensions of empathy. Rev Relig Res. 2009;51(2):201-19.

43. Paro HBMS, Silveira PSP, Perotta B, Gannam S, Enns SC, Giaxa RRB, et al. Empathy among medical students: is there a relation with quality of life and burnout? PloS One. 2014;9(4):e94133.

44. Brazeau CMLR, Schroeder R, Rovi S, Boyd L. Relationships between medical student burnout, empathy, and professionalism climate. Acad Med J Assoc Am Med Coll. 2010;85(10 Suppl):S33-36.

45. Hawthorne DL, Yurkovich NJ. Human relationship: The forgotten dynamic in palliative care. Palliat Support Care. setembro de 2003;1(03) [access in 15 jun 2017]. Available from: http://www.journals.cambridge.org/ abstract_S147895150303027X.

46. Koenig HG. Research on religion, spirituality, and mental health: a review. Can J Psychiatry Rev Can Psychiatry. 2009;54(5):283-91. 